\title{
CROP ROOT EXUDATES IN RELATION TO ESTABLISHMENT OF THE BIOCONTROL AGENT, Stenotrohomons maltophilia AGAINST BACTERIAL WILT OF POTATO. \\ Emara, H. M. ${ }^{1}$; Neveen A. Messiha ${ }^{2}$; Souzan A. Abdallah ${ }^{1}$ and K. M. Elhalag ${ }^{2}$ \\ 1: Faulty of Science, Benha University, 2:Potato Brown Rot Project, Agriculture research centre
}

\begin{abstract}
Potato brown rot is an important quarantine disease, caused by Ralstonia solanacearum race 3 biovar 2, Phylotype II, sequevar 1. Cow pea and maize crops, cultivated in clay soil, supported the highest survival of the biocontrol agent, Stenotrophomonas maltophilia under green house conditions. Meanwhile, the biocontrol agent disappeared quickly from soil cultivated with tomato or non-cultivated soil. The survival of $S$. maltophilia in soil had a significant negative correlation with potato brown rot incidence, as expressed by wilt severity, area under disease progress curve (AUDPC) as well as the count of pathogen in soil, rhizospher and crown area of potato plants. The amino acid analysis in root exudates of crops under investigation showed high ratio of asparagine, glutamine, and methionine (sulfur containing amino), in both cow pea and maize plants and high percentage of arginine and lysine in tomato root exudates. Tomato plants which considered as host for pathogen containing amino acids in their root exudates that act as attractant signals that made the pathogen more survived in soil. It can be concluded that cow pea and maize are recommended crops to be used for crop rotation with potato. The two crops are able to colonize $S$. maltophilia bacteria as biocontrol agent, in their rhizosphere that support establishment of the biocontrol agent and hence sustainable control for bacterial wilt of potato.
\end{abstract}

\section{INTRODUCTION}

Potato (Solanum tuberosum) is one of the most important vegetable crops in Egypt due to its high carbohydrate and starch contents. Egypt is the largest potato producer in Africa, producing annually about 1.5-2 million tons from 200.000 Fadden.

Potato crop subjects to several diseases that seriously affect the quality and quantity of its national yield as well as exporting to Europe. Brown Rot (bacterial wilt) is the major disease that causes a tremendous loss of the yield of the potato. Bacterial wilt caused by Ralstonia solanacearum was reported on tobacco, tomato and groundnut in Asia, southern USA and South America (OEPP/EPPO Bulletin, 2004). International trade in potatoes assumes zero tolerance for brown rot infection European Communities, 2005; Elphinstone et al., 1998; Janse, 1996). Latent infected potato tubers has results in threaten of ban for potato Egypt exports to Europe in the past (Farag et al., 1999). The pathogen can persist for a long time in soil, in infected host plant debris or by colonizing potato volunteer plants, alternative 
hosts or even non-host plants (Graha et al., 1979; Granada and Sequeira, 1983; Akiew and Trevorrow, 1994) and weed hosts such as Solanum dulcamara, S. nigrum, Portulaca oleracea in Europe (Elphinstone, et al., 1998) and Rumex dentatus and Solanum nigrum in Egypt (Farag et al., 2004).

Plants can communicate extensively, using secondary metabolites to express messages (Degenhardt et al., 2003 and Dicke and Hilker, 2003). Root exudates are compounds released into the surrounding medium by healthy and intact plant roots (Kalburtj and Mosjidi, 1993). Such compounds secreted by plant roots (Low-molecular weight compounds such as amino acids, organic acids, sugars, phenolics) serve important roles as chemical attractants and repellants in the rhizosphere (Estabrook and Yoder, 1998) and (Bais, 2001).

Root-microbe communication can either be a positive (symbiotic) to the plant, or negative to the plant, including interactions with parasitic plants, pathogenic bacteria, fungi, and insects (Ryan and Delhaize, 2001). Biological control of tremendous pathogen in soil is now considered the advanced alternative mechanism to synthetic pesticide due to its safety to environment and plant health as well as to the main aim (human health) (Brimmer and Boland , 2003). S. maltophilia isolated from rhizosphere of egg plant in Egyptian soil was firstly used as an antibacterial agent by (Messiha et al., 2007 ) as their ability to suppress $R$. solanacearum on king's media. Biocontrol bacteria able to produce serine protease enzyme (Miyaji, et al., 2005) which mostly the main antibacterial factor that cause degradation of pathogen cell wall by cleavage of protein cell wall into peptides and amino acids.

The aim of this study was to study the survival of the biocontrol agent in rhizosphere of three different crops and correlate this survival with amino acid fractionations of plant root exudates. The relation between survival of the biocontrol agent and disease suppression was investigated.

\section{MATERIALS AND METHODS}

\section{Plant materials}

Potato seed-tubers (Lady Rosetta Cv.) provided by the Potato Brown Rot Project (PBRP), Agric. Res. Center, Giza, Egypt from (MABA Co.).

\section{Source of soil}

Clay soil samples collected from El-Gharbia governorate were examined for absence of $R$. solanacearum. Sandy soil samples were collected from El-Behira Governorate from pest free area approved by (PBRP).

\section{Origin of the isolates}

Pathogen Isolates:

Pathogen isolates, three highly virulent isolates of $R$. solanacearum (K3, $\mathrm{K} 10, \mathrm{~K} 16$ ), originally isolated from diseased potato tubers showing typical brown rot symptoms from El-Dakahlia, and El-Monofia governorates in the Nile Delta of Egypt, by (Elhalag, 2008). The three isolates showed high percentage of wilt infection and disease severity on tomato plants. 


\section{Biocontrol isolates:}

\section{S. maltophilia isolates}

A lyophilized mutant rifampicin and chloramphenicol resistant $S$. maltophilia strain (PD4560), was originally obtained from Dr. NAS Messiha (Researcher, Agriculture research centre, Giza, Egypt). The original wild strain (PD 3533) was previously selected from 4 different strains originally isolated from the rhizosphere of eggplant (Solanum melongena; Black Beauty) (Messiha, 2001). Lately the strain (PD 3533) was spontaneously adapted to grow on $100 \mathrm{ppm}$ rifampicin and chloramphenicol, for easy trace back (Messiha, 2007) and its antagonistic characteristics were then checked and compared to the wild strain.

\section{Detection of disease incidence of potato plants after crop rotation with} different crop

\section{First part of the experiment:}

In the first part of the experiment two types of soils (clay and sand) were used. The soils were examined previously for the absence of potato brown rot bacteria. Three types of crops maize, cow pea and tomato plants were used in this experiment. Maize (cv. Single hyperdized 168), cow pea (cv. Kaha 1) and tomato plants (Lycopersicon esculentum cv. Pinto). The conditions of glasshouse (at PBRP Dokki, ARC) were fixed $\left(28-30^{\circ} \mathrm{C}\right.$ daytime, $16^{\circ} \mathrm{C}$ at night, $75-85 \% \mathrm{RH}$ and 16 hours light). Four replicates were designated for each of the three crops with consideration of four pots as control (i.e. 16 pots). Pots were $15 \mathrm{~cm}$ in high and $15 \mathrm{~cm}$ in diameter, holding three $\mathrm{kg}$, filled with either non-sterilized clay soil (16 pots) or sand soil (16 pots).

\section{Application of the biocontrol:}

S. maltophilia (PD 4560) was applied to each pot. A suspension of biocontrol strain was prepared in sterile distilled water and adjusted spectrophotometrically to approximately $4.285 \times 10^{9} \mathrm{CFU} / \mathrm{ml}$. The inoculums were added at rate of $1: 10$ (vol /wt) to achieve about $5 \times 10^{8} \mathrm{CFU} / \mathrm{g}$ dry soil. Soil and inoculum were mixed thoroughly. All pots were irrigated by tap water. The bacterial count for the biocontrol agent was observed during the experiment at $0,3,5,10,14,21,30,60,90$ days, respectively from the day of soil inoculation. Bacterial count of S. maltophilia (PD4560) was observed on (TSBA) media; amended with $100 \mathrm{mg}$ chloramphenicol and $100 \mathrm{mg}$ rifampicin 1:1 (Messiha et al., 2007).

\section{Root Exudates collection}

Root exudates from different plant cultivars were separately collected after a period of 80 days according to (Graham et al., 1981and Neal et al., 2012).

\section{Determination of the population count of biocontrol (S. maltophilia).}

The count of S. maltophilia (PD4560) in different plant root exudates were detected in all replicates for each plant by plating on (TSBA) amended with $100 \mathrm{ppm}$ rifampicin and chloramphenicol media, two types of soil used in this experiment were sent to (Soils, water and environment research institute, Giza , Egypt) for Chemical analysis and detection of available micro and macro elements in each soil sample. 


\section{Determination of the population count (survival) of pathogen}

After recording the count of $S$. maltophilia in root exudates about $1 \mathrm{ml}$ of each plant root exudates were inoculated by $50 \mu$ of $R$. solanacearum suspension of three virulent bacteria (Elhalag, 2008); to study the survival of $R$. solanacearum in root exudates in presence of $S$. maltophilia (PD 4560) and the count of $R$. solanacearum were observed during $0,10,20,40$ days from root exudates inoculation by plating on SMSA media (Elphinstone et al., 1996).

The collected root exudates were filter-sterilized under vacuum suction apparatus (Pall, Life sciences, USA) $(0.22-\mu \mathrm{m}$ filter, Millipore) and stored at $20^{\circ} \mathrm{C}$ in the dark for further study.

\section{Analysis of different root exudates}

Amino acid of different root exudates were carried out at Cairo University, Agriculture laboratories, using automatic amino acid analyzer (AAA400, INGOS Ltd.) and hydrolysis for all samples was performed according (Block et al., 1958).

\section{Second part of the experiment}

Maize, cow pea and tomato plants were removed and soil was infested by suspension of $R$. solanacearum. Two soil types were infested with a 1:1:1 mixture of the virulent strains (K3, K10, and $\mathrm{K} 16)$. The ratio of inoculum/soil was 1:10 (vol /wt). After soil infestation, potato tubers (Laddy rosetta cv.) were cultivated in all pots including controls and irrigation was done by tap water. Count of both bacteria ( $R$. solanacearum and S.maltophilia ) were monitored in soil at $0,40,70$ days since soil infestation while the count of both strains in the rhizosphere and roots were monitored at the end of the experiment (70 days).Wilting of the potato plants was recorded daily till the end of the experiment. Disease severity was recorded using the scale adapted by (Kempe and Sequeira, 1983)

\section{Statistical analysis}

Survival of $S$.maltophilia and pathogen in two types of soil (clay and sand) cultivated with different crops (Cow pea, maize and tomato) followed by survival of $R$. solanacearum in different crop root exudates as well as in water control experiment. Log transformed count of the two bacteria fitted to a standard logistic model with an asymptote as described by (Franz et al., 2005. The goodness of the data fitting to the model $\left(R^{2}\right)$ was calculated. The estimated parameter values $c$ and $d$ for the different managed substrates were first calculated from analytical analysis using SAS v. 9.1 (SAS Institute Inc., Cary, NC, USA) and then subjected to multivariate analysis of variance (MANOVA, using SPSS v 16, SPSS Inc., Chicago, Illinois, USA) to detect differences between survival of $S$. maltophilia in different soil types cultivated with different crops. Descriptive and NPar Tests (Mann-Whitney Test) analysis were conducted using SPSS v16 for comparison between disease severity, (AUDPC) and log transformed CFU count of both S. maltophilia and pathogen in soil, rhizospere and crown area after 70 days from soil inoculation (T70) according to soil types as well as crop types. For comparison between chemical compositions (amino acid analysis) of different crop root exudates paired T-test was conducted using SPSS v16. Correlation analyses were conducted between survival (C and D) for both $S$. maltophilia 
\& pathogen and different amino acid percent found in all crop root exudates amino acid contents SPSS V16.

\section{RESULTS}

Survival of S. maltophilia in three different crops grown in two soil types.

It is indicated from data in Fig. (1), that the decline in log-transformed CFU count of $S$. mlatophilia was lowest in clay and sand soils cultivated with cowpea and maize crop than those cultivated with tomato and non cultivated soil (control) respectively. S. maltophilia was highly survived in soil cultivated with cowpea and maize, while the lowest survival was found in non cultivated soil (control) and those cultivated with tomato.

\section{A. Clay soil}

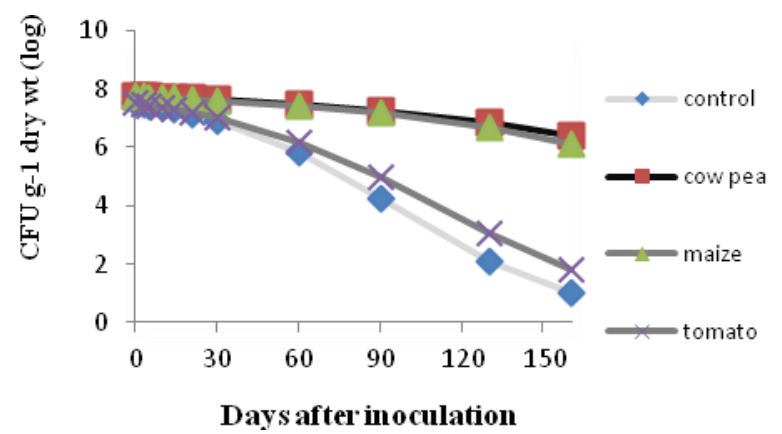

B. Sand soil

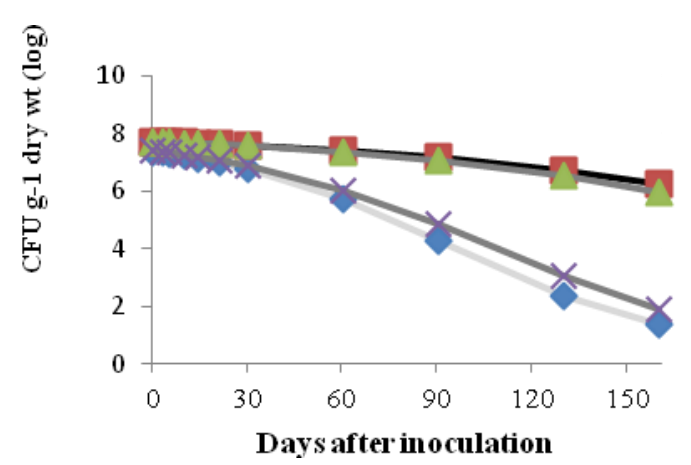

Fig. (1). Decline in density (CFUs $\mathrm{g}^{-1}$ dry soil) of $\mathrm{S}$. maltophilia in different crops cultivated in clay soil, experiment 2 . The lines are the predicted values from the logistic decline model:

$\mathrm{C}_{\mathrm{t}}=\mathrm{a}_{\mathrm{m}} /\left(1+\exp \left(-\mathrm{d}^{*}(\mathrm{t}-\mathrm{c})\right)\right)$. Where $\mathrm{C}_{\mathrm{t}}=\log$ transformed number of bacteria, $\mathrm{a}_{\mathrm{m}}=$ initial count of the pathogen (asymptote), $d=$ decline rate (days ${ }^{-1}$ ), and $t=$ time (days) and $c_{2}=50 \%$-reduction-time in days (Franz et al., 2005).

The $\mathbf{R}^{2}$ for the fit of the data to the logistic model with asymptote were around 0.95 for all treatments. 
There is no difference between survival of $S$ maltophilia in clay soil and sand soil. The observed values fit well to the logistic decay model with asymptote, with $\mathrm{R}^{2}$ values around 0.95 for clay soil and 0.97 for sand soil Fig.(1). Comparing $S$. mlatophilia survival in different crop was significant in all soils (MANOVA: Wilk's Lambda $\left(1.9 \times 10^{2}\right)$ for crop, (17.1) for soil: $\left.P<0.001\right)$ Where $\mathrm{F}$ value for crop (C: $1.74 \times 10^{3}, P<0.001$ and $\mathrm{D}: 152.1, P<0.001$ ). There was a significant difference in survival of $S$. maltophilia in clay and sand soil. The decline rate (D) was slightly higher in sand as compared to clay soil and $\mathrm{F}$ value for soil (C: $0.87, P>0.05$ and $\mathrm{D}: 6.1, P<0.02$ ).

Survival of $\boldsymbol{R}$. solanacearum in three different crops cultivated in two types of soil.

Data in Fig. (2) indicated that the decline in log-transformed CFU count of $R$. solanacearum was highest in soils cultivated with cowpea and maize crop than non cultivated soil (control) and those cultivated with tomato respectively giving similar results for clay and sand soil. $R$. solanacearum survived highly in soil cultivated with tomato or non cultivated soil (control), while the lowest survival was found in soil cultivated with maize or cowpea. There is no difference between survival of $R$. solanacearum in clay and sand soils. The observed values fit well to the logistic decay model with asymptote, with $\mathrm{R}^{2}$ values around 0.98 for clay soil and 0.94 for sand soil Fig. (2). Comparing $R$. solanacearum survival in different crop there was significant difference in pathogen survival in different cultivated soils (MANOVA: Wilk's Lambda $\left(1.5 \times 10^{3}\right)$ for crop, $(5.32)$ for soil: $\left.P<0.001\right)$ Where $F$ value for crop (C: $1.75 \times 10^{3}, \mathrm{P}<0.001$ and $\left.\mathrm{D}: 58.6, P<0.001\right)$.

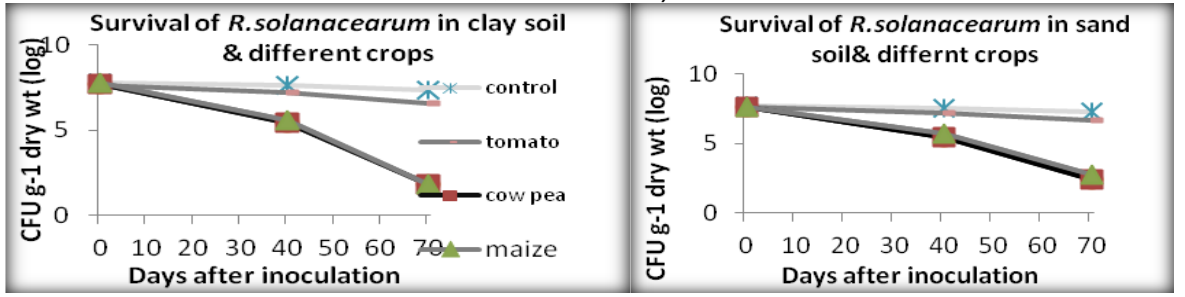

Fig. (2). Decline in density (CFUs $g^{-1}$ dry soil) of $R$. solanacearum in different crops cultivated in clay soil. The lines are the predicted values from the logistic decline model:

$C_{t}=a_{m} /\left(1+\exp \left(-d^{*}(t-c)\right)\right)$. Where $C_{t}=\log$ transformed number of bacteria, $a_{m}=$ initial count of the pathogen (asymptote), $\mathbf{d}=$ decline rate (days ${ }^{-1}$ ), and $\mathbf{t}=$ time (days) and $c=50 \%$-reduction-time in days (Franz et al., 2005).

The $\mathbf{R}$ for the fit of the data to the logistic model with asymptote were around 0.98 for all treatments.

Survival of $R$. solanacearum in three different crops root exudates cultivated in two types of soil contained S. maltophilia (PD4560).

Data in Fig. (3) Showed that the decline in log-transformed CFU count of $R$. solanacearum was the highest in root exudates of cowpea and maize cultivated in both soil than water (control) and those of tomato respectively. $R$. solanacearum was highly survived in root exudates of crop of tomato followed by water (control), while the lowest survival was found in root 
exudates of maize followed by those of cowpea. Soil type didn't affect the survival of $R$. solanacearum in root exudates of different crops cultivated in clay soil and sand soil. The observed values fit well to the logistic decay model with asymptote, with $\mathrm{R}^{2}$ values around 0.99 for clay soil and 0.99 for sand soil and 0.99 for water (control) Fig. (3). Survival of R. solanacearum in different crop was significant in both soils (MANOVA: Wilk's Lambda (76.7) for crop, (3.1) for soil: $P<0.001)$ Where $\mathrm{F}$ value for $\operatorname{crop}(\mathrm{C}=93.7, P<0.001$ and $\mathrm{D}: 9, P<0.001)$. There is no difference in survival of $R$. solanacearum in root exudates of any crop under investigation when grown in clay or sand soil. Correlation test between survival of $R$. solanacearum, as expressed by $c$ and $d$ values, in different crop root exudates and log transformed CFU count of $S$. maltophilia persist in root exudates showed that there is a significant negative correlation between both parameters where $r=(-0.88$ for $\mathrm{C}, P$ $<0.001$; D: $-0.51, P<0.009$ ).

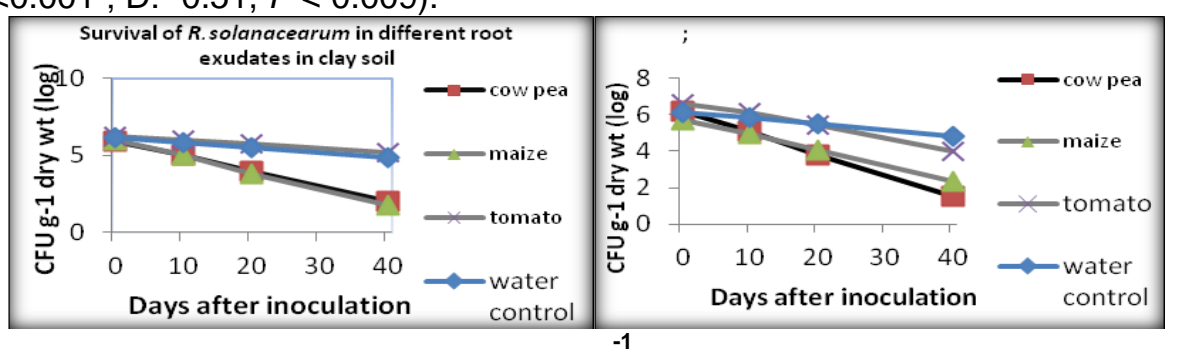

Fig. (3) Decline in density (CFUs $\mathrm{g}^{-1}$ dry soil) of R.solanacearum in different plant root exudates cultivated in clay soil. experiment 2. The lines are the predicted values from the logistic decline model:

$\mathrm{C}_{\mathrm{t}}=\mathrm{a}_{\mathrm{m}} /\left(1+\exp \left(-\mathrm{d}^{*}(\mathrm{t}-\mathrm{c})\right)\right)$. Where $\mathrm{C}_{\mathrm{t}}=\log$ transformed number of bacteria, $\mathrm{a}_{\mathrm{m}}=$ initial count of the pathogen (asymptote), $d=$ decline rate (days ${ }^{-1}$ ), and $t=$ time (days) and $c=50 \%$ reduction-time in days (Franz et al., 2005).

The $\mathbf{R}^{2}$ for the fit of the data to the logistic model with asymptote were around 0.99 for all treatments

\section{Disease incidence of potato brown rot after different crops cultivated in two types of soil}

Data in table (1) showed that disease severity and AUDPC Fig. (4) was reduced in both soils (clay and sand) of potato plant previously cultivated with cow pea and maize crops while increased in those cultivated with tomato plants as well as non cultivated soil (all soils pre-inoculated with $S$. maltophilia). The log transformed CFU count of $R$. solanacearum that was detected in soil, rhizosphere and crown area of potato plants Fig. $(5,6)$ that was previously inoculated with $S$. maltophilia and cultivated with cowpea and maize less than detected in tomato and non cultivated respectively. On the other hand the log transformed CFU count of $S$. maltophilia that was detected in soil, rhizosphere and crown area Fig.(7) of potato plant previously cultivated with cowpea and maize more than detected in those previously cultivated with tomato and non cultivated soil respectively. 
Emara, H. M. et al.

T1

1468 
There was no difference between count of $R$. solanacearum in both clay and sand soil as well as the count of $S$. maltophilia. Data in table (6) revealed that the count in rhizoshere of potato plants was higher than the count in both soil and crown area respectively. The statistical analysis (non parametric analysis) was conducted using SPSS v16 showed a significant difference in disease incidence after maize and cowpea from one side and tomato and control from the other side previously cultivated in both soil (clay and sand) according to all parameters (Disease severity, AUDC, $\log R$. solanacearum and $S$. maltophilia count in soil, rhizosphere and soil) where $p<0.01$ for all parameters, but there is no significant difference according to soil type. The mean rank of two types of soil previously cultivated with tomato and non cultivated soil was higher in disease severity, AUDPC and log count of $R$. solnacearumin soil, rhizosphere and crown area of potato plants than those previously cultivated with cowpea and maize respectively, on the other hand the mean rank was higher in case of $S$. maltophilia log CFU count in soil, rhizosphere and crown area previously cultivated with cowpea and maize than in tomato and non cultivated soil Fig. (8). The amino acid analysis for different root exudates of different crops shown in Table (2) showed that asparagine percent was high in cowpea root exudates (around 21\%) followed by maize (around 16\%) and tomato (around 6\%) respectively in both types of soil in which previously cultivated. Glutamine amino acid was higher in maize root exudates (around 20\%) than in cowpea (around 16\%) and tomato root exudates (around 7\%) respectively in both soils. Methionine amino acid was found only in cow pea (around 9\%) and maize root exudates (around 7\%) and was not found on the tomato root exudates. Arginine (around 27\%) was found higher in tomato root exudates than those of cow pea (around 11\%) and maize (around 7\%) respectively. Lysine was found in highest percentage in tomato root exudates (around 22\%), while in cow pea and maize (around $3 \%)$. Lysine was found in cow pea cultivated in clay soil (7\%), while not found in those cultivated in sand soil. No clear difference in amino acid fractionation of the same crop grown in the two soil types. The Correlation test using SPSS v16 between C, D value for both $R$. solanacearum and $S$. maltophilia and amino acid found in different crop root exudates revealed a significant positive correlation between percent of (asparagines and glutamine amino acids) and (c, d) value for $S$. maltophilia where $R=(C:+0.95), P=0.004$, (D: $+0.93), P=0.006$ and negative correlation with $\mathrm{c}, \mathrm{d}$ value for $R$. solanacearum $\mathrm{R}=(\mathrm{C}:-0.93), P=0.007$, (D: 0.85$), P=0.032$, in case of methionine there is a positive correlation with (c, d) value for $S$. maltophilia where $R=(C:+0.98)$, $P<0.001,(\mathrm{D}:+0.97), P<0.001$ and negative correlation with $\mathrm{c}, \mathrm{d}$ value for $R$. solanacearum $\mathrm{R}=(\mathrm{C}$ : -0.99$), P<0.001$, (D: 0.93), $P<0.006$, but in case of arginine there is a negative correlation with (c, d) value for $S$. maltophilia where $\mathrm{R}=(\mathrm{C}:-\mathrm{0}$.95), $P=0.004$, (D: -0.95$), P=0.003$ and positive correlation with $\mathrm{C}$, $\mathrm{d}$ value for $R$. solanacearum; $\mathrm{R}=(\mathrm{C}:+0.99), P=0.009$, (D: +0.93$)$, $P=0.009$. 
Emara, H. M. et al.

Fig. (4) Correlation between different crops and disease severity, AUDPC

Fig. (5) Correlation between different crops and log CFU of $R$. solancearum in soil and rhizoshere (T70)

Fig. (6) Correlation between different crops and log CFU of R.solancearum in crown area (T70) and log CFU of S. maltophilia in soil (T70) 
Fig. (7) Correlation between different crops and log CFU of $S$. maltophilia in rhizoshere andcrown area (T70)

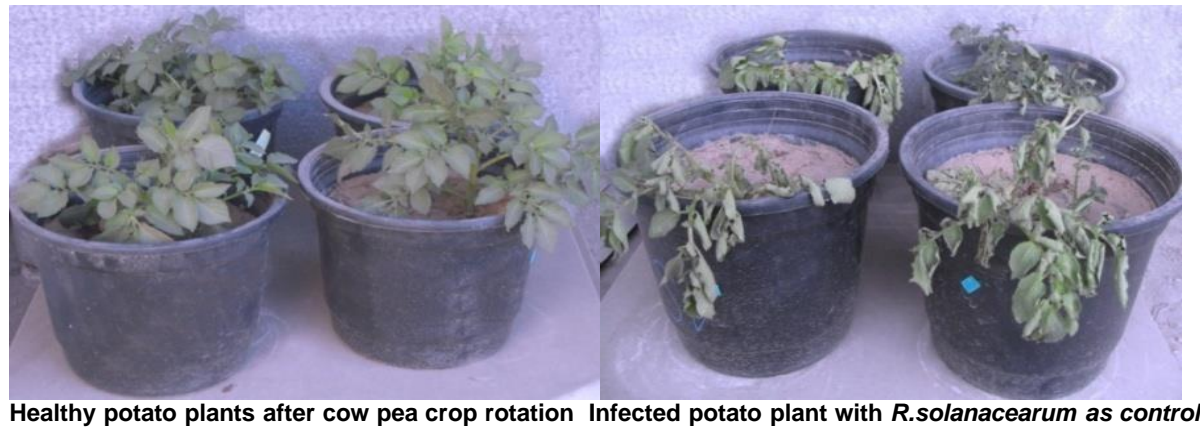
Healthy potato plants after cow pea crop rotation Infected potato plant with R.solanacearum as control
Fig. (8) Healthy Potato after cow pea crop rotation compared to infected potato plant with R.solanacearum

Table (2) Amino acid analysis for different root exudates of different crops

\begin{tabular}{|c|c|c|c|c|c|c|c|}
\hline $\begin{array}{c}\text { Peak } \\
\text { Name }\end{array}$ & $\begin{array}{c}\text { Cow pea In } \\
\text { clay soil }\end{array}$ & $\begin{array}{c}\text { Cow pea } \\
\text { in sand } \\
\text { soil }\end{array}$ & $\begin{array}{c}\text { Maize in } \\
\text { sand soil }\end{array}$ & $\begin{array}{c}\text { Maize in } \\
\text { clay soil }\end{array}$ & $\begin{array}{c}\text { Tomato in } \\
\text { clay soil }\end{array}$ & $\begin{array}{c}\text { Tomato in } \\
\text { sand soil }\end{array}$ & Standard \\
\cline { 2 - 8 } & \multicolumn{7}{|c|}{ Amino Acid concentration \% } \\
\hline Asp $^{*}$ & 22.55 & 20.75 & 16.45 & 14.88 & 5.87 & 7.42 & 6.47 \\
\hline Glu $^{*}$ & 17.61 & 15.73 & 20.28 & 19.45 & 6.60 & 7.74 & 7.34 \\
\hline Met $^{*}$ & 8.38 & 9.78 & 8.5 & 6.2 & 0 & 0 & 8.10 \\
\hline Arg $^{*}$ & 8.32 & 12.32 & 9.74 & 5.75 & 27.30 & 26.62 & 5.12 \\
\hline
\end{tabular}
0.001

\section{DISCUSSION}

The main aim of this study was to increase sustainability of the biocontrol agent by selection of suitable crops that enhance the survival of $S$. maltophilia in the soil and can be used in crop rotation with potato plants. 
Increasing the sustainability of the biocontrol agent will result in potato brown rot suppression. Decline in log-transformed CFU count of $S$. mlatophilia was slowest in clay and sand soils cultivated with cowpea and maize crop as compared to those cultivated with tomato and non cultivated soil (control) respectively. S. maltophilia showed highest survival in soil cultivated with Cowpea and maize and lowest survival in non cultivated soil (control) and soil cultivated with tomato. The highest survival in soil cultivated with cow pea and maize was explained by extraction of different crop root exudates and analysis for amino acid. This analysis revealed high ratios of asparagines and glutamine amino acids in cowpea and maize as compared to tomatoes root exudates, while methionine was found only in cowpea and maize root exudates. These amino acids in root exudates act as a nutrient source (Dakora and Phillips, 2002) which enhance the survival of S. maltophilia. Methionine is considered as sulfur containing amino acids which support the highest survival of $S$. maltophilia in rhizosphere of cow pea and maize. Debette and Blondeau, (1980) reported that $S$. maltophilia is a common microorganism in the rhizosphere of cruciferous plants (Lambert and Joos, (1989), and has also been found in association with corn and beets and this association is promoted by the high content of sulfurated amino acids in root exudates, which are growth factors for $S$. maltophilia. Xanthomonas species are chemoorganotrophic. In purely synthetic media containing minerals, ammonium nitrogen, and suitable carbon source such as glucose, amino acid supplements are required by most strains of all species. Usually glutamate or methionine, but occasionally both, are needed (Saddler and Bradbury, 1995). On the other hand, methionine may play a role in pathogenesis, as studies on methylthiopropionic acid (MTPA), a phytotoxin produced by $X$. axonopodis pathovar manihotis, Ewbank and Maraite, (1990) have demonstrated that methionine is a precursor of MTPA. Many strains of Stenotrophomonas require the addition of growth factors (methionine or cystine plus glycine) for growth on chemically defined media. Stimulation of growth by the sulphur containing amino acids was present in $100 \%$ of S. maltophilia strains by (Van Den Mooter and Swings, 1989).

In our study, there was no clear difference between survival of $S$ maltophilia in clay soil and sand soil while the crop had a great effect in survival of the biocontrol agent. Root exudates may act as messengers that communicate and initiate biological and physical interactions between roots and soil organisms (Walker et al., 2003). Amino acids have been suggested to represent minor components of maize root exudate (Kraffczyck, 1984 and Vančura, 1964); however, as suggested by Peters and Verma (Peters, and Verma, 1990) genes encoding functions with regard to specific interactions with plant roots may have evolved from bacterial catabolic genes, which were originally necessary for bacterial carbon and nitrogen acquisition; amino acids that function as specific chemoattractants for micro-organisms.

Decline in log-transformed CFU count of $R$. solanacearum was highest in soils cultivated with potato and pre- cultivated with cowpea and maize crop than non cultivated soil (control) and those cultivated with tomato respectively giving similar results for clay and sand soil. $R$. solanacearum survived highly in soil pre cultivated with tomato pre-inoculated with $S$. maltophilia and non 
cultivated soil (control) as both tomato and potato plants is highly susceptible hosts for $R$. solanacearum (He et al., 1983) so, they can easily attack and colonize their roots by chemotatic attract of tomato root exudates to their pathogen where arginine amino acid found in highly concentration in tomato root exudates was thought to play important role in $R$. solanacearum colonization as well as in chemotaxis between tomato plant and $R$. solancearum bacteria. Bacilio-jimenez et al., (2003) concluded that, root exudates (amino acids, carbohydrates) of rice represent an important source of nutrient for microorganisms but also participate in early colonization of inducing chemotatic responses of rhizospheric bacteria such as Corynebacterium flavescens and Bacillus pumilus. The highest survival of $R$. solanacearum in soil pre cultivated with tomato was accomplished by low $S$. maltophilia survival in soil cultivated with tomato. On the other hand, the lowest survival of the pathogen was found in soil pre cultivated with maize or cowpea pre-inoculated with $S$. maltophilia which was accomplished by highest survival of $S$. maltophilia in those soils pre cultivated with cow pea and maize crops. In conclusion, sulfur containing amino acids root exudates of maize and cowpea supported S. maltophilia growth and survival and hence suppressed the potato brown rot disease regardless to the soil type.

The presence of $S$. maltophilia in to root exudates of cow pea and maize reduced the count of $R$. solanacearum by producing protease enzyme that degrade the protein in cell wall (Miyaji, et al., 2005) of $R$. solanacearum causing the cell death, while lowest count of $S$. maltophilia couldn't survive in tomato root exudates and was unable to reduced the count of $R$. solanacearum in tomato root exudates. On the other hand tomato root exudates containing suitable amino acids that support the survival of $R$. solanacearum such as arginine amino acid which found in highly concentration in tomato root exudates acting as nutrient source.

Addition of $S$. maltophilia to clay and sand soils cultivated with cow pea or maize crop and then cultivated with potato plants decreased the disease severity and area under disease progress curve (AUDPC) of potato plants by $97 \%$ comparing to control previously non cultivated as well as the log transformed CFU count of $R$. solanacearum in soil, rhizoshpere and crown area of potato plants, while addition of $S$. maltophilia failed to decrease them in those pre cultivated with tomato plants as well as non cultivated soil (all soils pre-inoculated with $S$. maltophilia). In our study, S. maltophilia could persist and survive for long time till potato cultivation and in $R$. solanacearum infested soil. As the biocontrol agent could suppress the pathogen and protect potato plants root from pathogen attacked.

It is concluded that cow pea and maize serve as an excellent niche to the biocontrol agent S. maltophilia helping in its sustainability and establishment after soil inoculation. 


\section{ACHNOWLEDGEMENT}

life.

Firstly, my unlimited thanks to ALLAH for all things who given me in my

I would like to express my deepest thanks and gratitude to Potato Brown Rot Project for supporting me with equipments and different chemicals as well as the cost of amino acid analysis.

A word of gratitude is not enough towards the great effort and help of Prof. Dr. Abuserieh Mahmoud Ismail. Professor of Plant Pathology, Agricultural research centre, Head of potato brown rot project for

his conntinous valuable advice, support and for facilitating everything to conduct this research.

Deepest thanks and appreciation are also to Dr. Nader Elbadry Researcher, potato brown rot project for his great support during preparation of this work and his help in putting the work in its final form.

Deepest thanks and appreciation are also Prof. Dr. Safwat AbdelHamid El-Haddad chief researcher of Plant Pathology, Institute of Plant Pathology, Agricultural research Center, Giza for his constructive supervision, valuable advice, support.

I give my full respect and thanks to my lovely parents, wife, kids and whom gave me love, support and encouragement all the time.

\section{REFERENCES}

Akiew E and Trevorrow PR (1994) Management of bacterial wilt of tobacco. In: Hayward AC and Hartman GL (eds.) Bacterial wilt: The disease and its causative agent, Pseudomonas solanacearum. CAB International, United Kingdom, pp. 179-198.

Ata, K. (2008) studying the interaction between potato brown rot bacterium and root exudates of certain crops.M.Sc.Thesis, Banha university, faculty of science.

Bacilio-Jimenez (2003) Chemical characterization of root exudates from rice (Oryza sativa) and their effects on the chemotactic response of endophytic bacteria. Plant Soil. 249: 271-277.

Bais, H. (2001). Root-specific metabolism: the biology and biochemistry of underground organs. In Vitro Cell. Dev. Biol. Plant 37: 730-741.

Block, R.; Durrum, J.; and Zweig, G. (1958) Annual of paper chromatography and paper electrophoresis second ed.Academic press, New York.7580.

Brimmer, T. and Boland, G. (2003) A review of the non target effects of fungi used to biologically control plant diseases. Agric.Ecosyst. Environ. 100: 3-16.Bulletin 26: 679-695.

Dakora, F.; and Phillips, D. (2002) Root exudates as mediators of mineral acquisition in low-nutrient Environments. Plant and Soil 245: 35-47.

Debette, J.; and Blondeau, R. (1980) Pre'sence de Pseudomonas maltophilia dans la rhizosphe're de quelques plantes cultive'es. Can. J. Microbiol. 26:460-463. 
Degenhardt, J.;Gershenzon, J.; Baldwin, I. (2003). Attracting friends to feast on foes: engineering terpene emission to make crop plants more attractive to herbivore enemies. Current Opinion in Biotechnol. 14: 169176.

Dicke, M. and Hilker, M. (2003). Induced plant defences: from molecular biology to evolutionary ecology. Basic and Applied Ecology. 4: 3-14.

Elphinstone JG, Stanford HM and Stead DE (1998) Detection of Ralstonia solanacearum in potato tubers, Solanum dulcamara, and associated irrigation water In: Prior P, Allen C and Elphinstone JG (eds.) Bacterial Wilt Disease: Molecular and Ecological Aspects. Springer,

Estabrook, E. and Yoder, J. (1998) Plant-plant communications: rhizosphere signaling between parasitic angiosperms and their hosts. Plant Physiol. 116: 1-7.

Elphinstone, J.; Hennessey, J.; Wilson, J.; and Stead, D. (1996) Sensitivity of different methods for the detection of Pseudomonas solanacearum in potato tuber extracts. Bulletin OEPP/EPPO Bulletin 26: 663-678.

European and Mediterranean Plant Protection Organization. Ralstonia solanacearum, (2004). Diagnostic protocols for regulated pests. Bulletin OEPP/EPPO Bulletin 34:173 -178.

European Communities (2005) Commission staff working paper as an annex to: "European Neighbourhood Policy" Country Report, Egypt 2-3-2005, SEC (2005) 287/3. (also see:

http://europa-eu-un.org/articles/nl/article_4414_nl.htm).

Ewbank, E.; and Maraite, H. (1990) Conversion of methionine to phytotoxic 3methylthiopropionic acid by Xanthomonas campestris pv.manihotis. J. of General Microbiol. 136: 1185-1189.

Farag, N.; Stead, D. and Janse, J. (1999). Short Communication. Ralstonia (Pseudomonas) solanacearum race 3, biovar 2, Detected in Surface (irrigation) Water in Egypt. Short Communication Potato Brown Rot Project (PBRP), Dokki, Cairo, Egypt. J. of Phytopathol. 147: 478- 485.

Franz, E; van Diepeningen, A.; de Vos, O.; and van Bruggen, A. (2005) Effects of cattle feeding regimen and soil management type on the fate of Escherichia coli $\mathrm{O} 157: \mathrm{H} 7$ and Salmonella enterica serovar Typhimurium in manure, manure-amended soil, and lettuce. Appl. and Environ. Microbiolo.71: 6165-6174.

Graham J, Jones DA and Lloyd AB (1979) Survival of Pseudomonas solanacearum race 3 in plant debris and in latently infected potato tubers. Phytopathol. 69: 1100-1103.

Graham, J.; Leonard, R.; and Menge, J. (1981) Membrane-mediated decrease in root exudation responsible for phorphorus inhibition of vesicular-arbuscular mycorrhiza formation. Plant Physiol.68: 548-552.

Granada GA and Sequeira L (1983) Survival of Pseudomons solanacearum in soil, rhizosphere and plant roots. Canadian Journal of Microbiology 29: 433-440.

He, L.; Sequeira, L.; and Kelman, A. (1983) Characteristics of Pseudomonas solanacearum from China. Plant Dis. 67: 1357-1361. 
Janse JD (1996) Potato brown rot in western Europe - history, present occurrence and some remarks on possible origin, epidemiology and control strategies. Bulletin OEPP/EPPO Berlin, Germany, pp. 133-139.

Kalburtji, L. and mosjidis, J. (1993). Effects of sericea lespedeza root exudates on some perennial grasses. J. Range Manage. 46:312-315.

Kempe, J.; and Sequeira, L. (1983) Biological control of bacterial wilt of potatoes attempts to induce resistance by treating tubers with bacterial. Plant dis., 67: 499.

Kraffczyck, I.; Trolldenier, G.; and Beringer, H. (1984) Soluble root exudates of maize: influence of potassium supply and rhizosphere microorganisms. Soil Biol. Biochem. 16:315-322.

Lambert, B.; and Joos, H. (1989) Fundamental aspects of rhizobacterial plant growth promotion research. Trends in Biotechnol. 7: 215-219.

Messiha, NAS (2001) Biological control of potato brown rot disease. M. Sc. Thesis, Faculty of Science, Zagazig University Egypt.

Messiha, NAS.; Diepeningen, A.; Farag, N. Abdallah, S.; Janse , J.; and Bruggen, A. (2007) Stenotrophomonas maltophilia: a new potential biocontrol agent of Ralstonia solanacearum, causal agent of potato brown rot. Eur. J. Plant. Pathol. 118: 211-225.

Neal, A.; Ahmad, S.; Gordon-Weeks, R.; 1, Ton, J. (2012) Benzoxazinoids in Root Exudates of Maize Attract Pseudomonas putida to the Rhizosphere. PLoS ONE 7(4): e35498. doi:10.1371/journal.pone.0035498.

Peters, N.; and Verma, D. (1990) Phenolic compounds as regulators of gene expression in plant-microbe interactions. Mol. Plant-Microbe Interact. 3: 4-8.

Ryan, P.and Delhaize, E. (2001). Function and mechanism of organic anion exudation from plant roots. Annu. Rev. Plant Physiol. Mol. Biol. 52: 527-560.

Saddler, G.; and Bradbury, J. (1995) Genus I. Xanthomonas Dowson 1939, 187AL emend. Vauterin, Hoste, Kersters and Swings1995, 483.

Van Den Mooter, M.; and Swings, J. (1990): Numerical analysis of 295 phenotypic features of 266 Xanthomonas strains and related strains and an improved taxonomy of the genus. Int. J. Syst. Bacteriol. 40: 348 - 369.

Vanc ura, V. (1964) Root exudates of plants, I. Analysis of root exudates of barley and wheat in their initial phases of growth. Plant Soil. 21:231248.

Walker, T.; Pal Bais, H.; Grotewold, E. and Vivanco, J. (2003) Root Exudation and Rhizosphere Biology. Plant Physiol.132: 44-51. 
افرازات جذور المحاصيل وعلاقتها بكفـاعة المقـاوم الحيوى سـترينوتروفوموناس

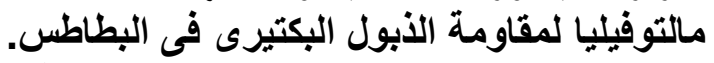

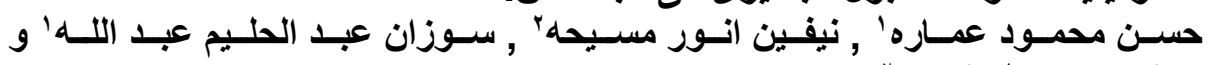

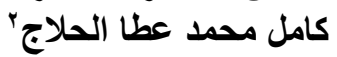

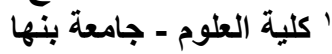

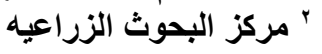

يعتبر مرض العفن البنى من الامر اض الحجريه و الذى يسببه بكتريا رالستونيا سو لاناسيرم

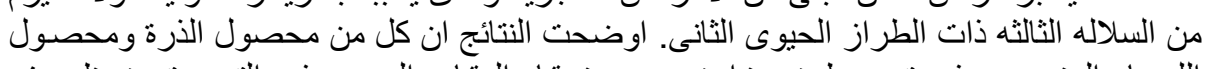

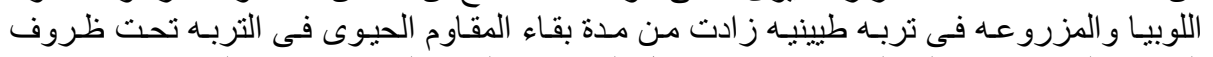

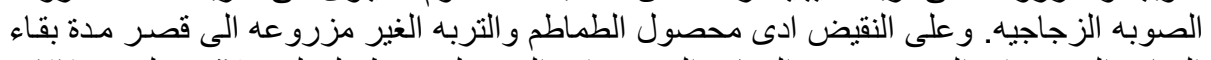

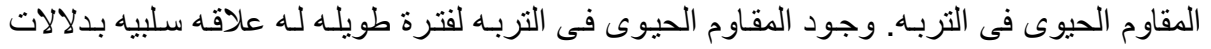

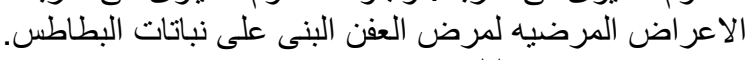

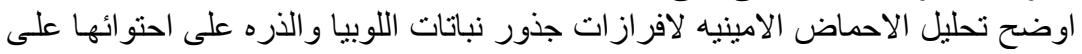

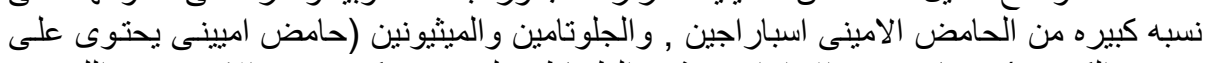

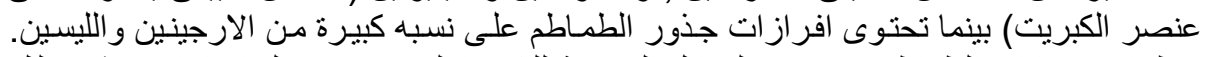

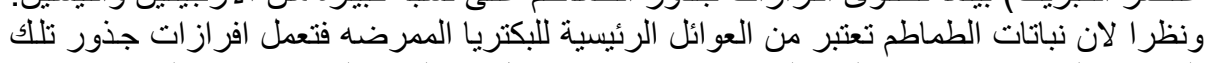

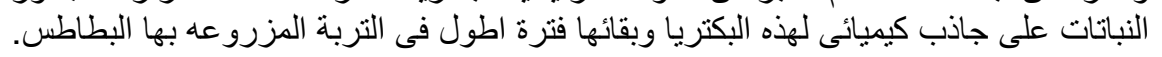

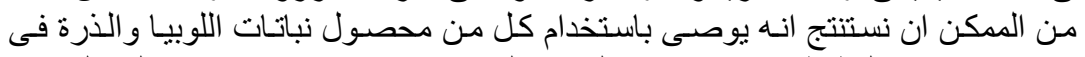

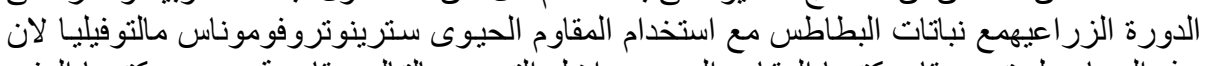

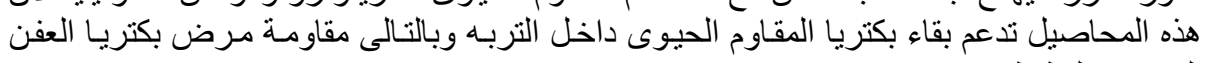
البنى فى البطاطس.

أ. أد / محب طنه صقر مئر قام بتحكيم البحث أ.د / حسنى طه مكرم الله كلية الزراعة - جامعة المنصورة مركز البحوث الزراعية 
Emara, H. M. et al. 
Table (1) Disease incidence of potato brown rot after different crops cultivated in two types of soil

\begin{tabular}{|c|c|c|c|c|c|c|c|c|c|c|c|c|c|c|c|c|c|}
\hline \multirow[t]{2}{*}{ Crop } & \multirow[t]{2}{*}{ Soil } & \multicolumn{2}{|c|}{$\begin{array}{l}\text { Disease* } \\
\text { severity }\end{array}$} & \multicolumn{2}{|c|}{ AUDPC $^{* 6}$} & \multicolumn{2}{|c|}{$\begin{array}{c}\mathrm{LOG}_{10} \mathrm{CFU}^{*} \\
\text { R.s }^{1} \text { soil }\end{array}$} & \multicolumn{2}{|c|}{$\begin{array}{l}\text { LOG }_{10} \text { CFU R.s R.s } \\
\text { Rhizosphere }^{*}\end{array}$} & \multicolumn{2}{|c|}{$\underset{\text { crown }^{3 \star}}{\text { LOG }_{10} \text { CFU R.s }}$} & \multicolumn{2}{|c|}{$\begin{array}{l}\mathrm{LOG}_{10} \mathrm{CFU} \\
\text { S. } m p h^{2} \text { soil }^{\star}\end{array}$} & \multicolumn{2}{|c|}{$\begin{array}{c}\mathrm{LOG}_{10} \text { CFU } \\
\text { S.mph Rhizo* }\end{array}$} & \multicolumn{2}{|c|}{$\begin{array}{l}\log 10 \mathrm{CFU} \\
\text { S.mph in } \\
\text { crown * }\end{array}$} \\
\hline & & $\begin{array}{l}\text { Mean } \\
\text { rank }\end{array}$ & $\begin{array}{c}\text { mean } \pm \\
\mathrm{SE}\end{array}$ & $\begin{array}{c}\text { Mean } \\
\text { rank }\end{array}$ & mean $\pm S E$ & $=\begin{array}{l}\text { Mean } \\
\text { rank }\end{array}$ & $\begin{array}{c}\text { Mean } \\
\pm \mathrm{SE}\end{array}$ & $\begin{array}{c}\text { Mean } \\
\text { rank }\end{array}$ & $\begin{array}{c}\text { Mean } \\
\pm \mathrm{SE}\end{array}$ & $\begin{array}{c}\text { Mean } \\
\text { rank }\end{array}$ & $\begin{array}{c}\text { Mean } \\
\pm \mathrm{SE}\end{array}$ & $\begin{array}{c}\text { Mean } \\
\text { rank }\end{array}$ & $\begin{array}{c}\text { Mean } \\
\pm \mathrm{SE}\end{array}$ & $\begin{array}{c}\text { Mean } \\
\text { rank }\end{array}$ & $\begin{array}{c}\text { Mean } \\
\pm \mathrm{SE}\end{array}$ & \begin{tabular}{|c|} 
Mean \\
rank
\end{tabular} & $\begin{array}{c}\text { Mean } \\
\pm \text { SE }\end{array}$ \\
\hline Maize $^{*}$ & Clay & 4.3 & $2 \pm 2$ & 4.3 & $\begin{array}{c}19.5 \pm \\
19.5\end{array}$ & 4 & $\begin{array}{c}1.8 \pm \\
0.29\end{array}$ & 3.8 & $\begin{array}{c}1.46 \pm \\
0.09\end{array}$ & 4.6 & $\begin{array}{c}0.17 \pm \\
0.17\end{array}$ & 10.7 & $\begin{array}{l}5.58 \pm \\
0.036\end{array}$ & 10.5 & $\begin{array}{c}6.32 \pm \\
0.04\end{array}$ & 10.5 & $\begin{array}{c}3.04 \pm \\
0.03\end{array}$ \\
\hline $\begin{array}{l}\text { Cow- } \\
\text { pea* }\end{array}$ & Clay & 4.6 & $\begin{array}{c}2.5 \pm \\
2.5\end{array}$ & 4.6 & $20 \pm 20$ & 5 & $\begin{array}{c}1.8 \pm \\
0.34\end{array}$ & 5.1 & $\begin{array}{c}1.54 \pm \\
0.06\end{array}$ & 4.3 & $\begin{array}{c}0.14 \pm \\
0.13\end{array}$ & 14.2 & $\begin{array}{l}5.68 \pm \\
0.009\end{array}$ & 14.5 & $\begin{array}{c}6.55 \pm \\
0.01\end{array}$ & 14.5 & $\begin{array}{r}3.23 \pm \\
0.02\end{array}$ \\
\hline Tomato* & Clay & 12.5 & $100 \pm 0$ & 11 & $\begin{array}{c}719.1 \pm \\
45.1 \\
\end{array}$ & 10.5 & $\begin{array}{l}6.7 \pm \\
0.02\end{array}$ & 11.5 & $\begin{array}{l}7.18 \pm \\
0.08\end{array}$ & 14 & $\begin{array}{l}5.34 \pm \\
0.01\end{array}$ & 5.5 & $\begin{array}{l}2.67 \pm \\
0.084\end{array}$ & 6.5 & $\begin{array}{c}2.45 \pm \\
0.02\end{array}$ & 5.2 & $\begin{array}{c}1.57 \pm \\
0.3\end{array}$ \\
\hline Control* & Clay & 12.5 & $100 \pm 0$ & 14 & $\begin{array}{c}841.5 \pm \\
32.4\end{array}$ & 14.5 & $\begin{array}{l}7.4 \pm \\
0.01 \\
\end{array}$ & 13.5 & $\begin{array}{l}7.31 \pm \\
0.07\end{array}$ & 11 & $\begin{array}{c}5.28 \pm \\
0.02\end{array}$ & 3.5 & $\begin{array}{c}2.22 \pm \\
0.32\end{array}$ & 2.5 & $\begin{array}{c}1.36 \pm \\
0.04\end{array}$ & 3.7 & $\begin{array}{c}1.42 \pm \\
0.2\end{array}$ \\
\hline Maize $^{*}$ & Sand & 4 & $0 \pm 0$ & 4 & $0 \pm 0$ & 5.2 & $\begin{array}{c}2.8 \pm \\
0.4\end{array}$ & 5.5 & $\begin{array}{c}3.01 \pm \\
0.48\end{array}$ & 4.2 & $\begin{array}{c}0.82 \pm \\
0.24\end{array}$ & 12.2 & $\begin{array}{l}5.39 \pm \\
0.045\end{array}$ & 10.5 & $\begin{array}{c}6.15 \\
\pm 0.04\end{array}$ & 10.5 & $\begin{array}{c}3.08 \pm \\
0.04\end{array}$ \\
\hline $\begin{array}{l}\text { Cow- } \\
\text { pea* }\end{array}$ & Sand & 5 & $\begin{array}{c}3.3 \pm \\
3.3 \\
\end{array}$ & 5 & $9.1 \pm 9.1$ & 3.7 & $\begin{array}{c}2.5 \pm \\
0.32 \\
\end{array}$ & 3.5 & $\begin{array}{c}2.22 \pm \\
0.31 \\
\end{array}$ & 4.7 & $\begin{array}{l}0.66 \pm \\
0.05\end{array}$ & 12.7 & $\begin{array}{c}5.45 \pm \\
0.04\end{array}$ & 14.5 & $\begin{array}{c}6.42 \pm \\
0.01 \\
\end{array}$ & 14.5 & $\begin{array}{c}3.24 \pm \\
0.01 \\
\end{array}$ \\
\hline lato* & Sand & 12.5 & $100 \pm 0$ & 11 & $\begin{array}{c}674.4 \pm \\
17.1 \\
\end{array}$ & 10.5 & $\begin{array}{l}6.7 \pm \\
0.01\end{array}$ & 12.2 & $\begin{array}{l}7.1 \pm \\
0.078\end{array}$ & 13.8 & $\begin{array}{c}5.27 \pm \\
0.02\end{array}$ & 5.5 & $\begin{array}{l}2.66 \pm \\
0.083 \\
\end{array}$ & 6.5 & $\begin{array}{c}2.35 \pm \\
0.01\end{array}$ & 5.7 & $\begin{array}{r}2.2 \pm \\
0.25 \\
\end{array}$ \\
\hline Control* $^{*}$ & Sand & 12.5 & $100 \pm 0$ & 15 & $\begin{array}{l}883.1 \pm \\
29.3\end{array}$ & 14.5 & $\begin{array}{c}7.3 \pm \\
0.01\end{array}$ & 12.7 & $7.17 \pm 0.1$ & 11.1 & $\begin{array}{l}5.2 \pm \\
0.022\end{array}$ & 3.5 & $\begin{array}{c}2.29 \pm \\
0.31\end{array}$ & 2.5 & $\begin{array}{c}1.62 \pm \\
0.21\end{array}$ & 3.2 & $\begin{array}{c}1.85 \pm \\
0.26\end{array}$ \\
\hline
\end{tabular}

$1=R$. solanacarum , $2=$ S. maltophilia , $3=$ Rhizosphere , $4=$ Crown area of potato plants , $5=$ Standard error. , $6=$ Area under disease progress curve $^{*}=$ Significance: $\mathrm{P}<0.001$ 
J. Plant Production, Mansoura Univ., Vol. 4 (10): 1461 - 1477, 2013 